\title{
Black Health Matters Too... Especially in the Era of Covid-19: How Poverty and Race Converge to Reduce Access to Quality Housing, Safe Neighborhoods, and Health and Wellness Services and Increase the Risk of Co-morbidities Associated with Global Pandemics
}

\author{
Richard B Duque ${ }^{1}$ (B) \\ Received: 14 July 2020 / Revised: 23 August 2020 / Accepted: 24 August 2020 / Published online: 18 September 2020 \\ (C) W. Montague Cobb-NMA Health Institute 2020
}

\begin{abstract}
Objectives This research offers an alternative to the singular focus on improving health services to the African American community to increase their resilience to health-related co-morbidities associated with Covid-19 deaths.

Methods This study employs a participatory action research (PAR) approach, where local non-profit organizations and researchers partnered with a challenged community in a self-study of intergenerational poverty related to health issues and the various obstacles to breaking this cycle.

Results A quantitative and qualitative analysis of interview and focus group data suggests that the majority of those living in poor neighborhoods report reducing intersectional factors that are the cause and function of intergenerational poverty would reduce poverty and by extension increase African Americans' resilience to health-related mortality.

Conclusions Analysis of data related to overlapping obstacles like lack of access to safe housing and quality health services offers both context and insight about how policies addressing poverty reduction may offer pathways for reducing the co-morbidities associated with pandemic risk for African Americans.
\end{abstract}

Keywords Food deserts · Housing · Intersectionality · Social disorganization · Race · Participatory action research · Health disparities $\cdot$ Covid-19

\section{Introduction}

When the 2019 novel coronavirus (Covid-19) pandemic spread from China, Europe, and then to the USA, media and health professional attention first focused on those most likely to be impacted by the virus. A first glimpse into the patterns of those most likely at risk were the elderly and those with underlying heart and pulmonary conditions. Then, what surprised many was how African Americans around the nation seemed to be the most at risk. As of June 2020, 23,253 Black lives have been lost to Covid-19 (Covidtracking.com). That is about $21 \%$ of total US pandemic deaths, where race has been identified, though African Americans make up only approximately $13 \%$ of the US populations. In other words, as of July 2020, African Americans were dying at a rate 1.5

Richard B Duque

Duqrick@gmail.com

1 George Washington University, Washington, D.C., USA times higher than their share of the US population. This begs the question as to why African Americans are more likely to die from this particular virus.

Recently, a consensus has emerged around the issue of chronic, intergenerational minority poverty, which suggests that the obstacles to overcoming self-sufficiency are often intersectional and interinstitutional. Poor, minority communities are more likely to be disadvantaged across a variety of institutional dimensions like unequal access to quality education, good-paying jobs, affordable housing, safe neighborhoods, quality food, and health services. Interconnected conditions like these have been observed to produce cumulative disadvantages across generations, supporting the assertion that growing up in a poor, minority community is the most significant predictor for life-long poverty and thus increased risk for health hazards like Covid-19 [25]. This suggests a follow-up question: is there a way to mitigate health risks experienced in African American communities?

This paper offers a glimpse of what redistributing attention and resources to creating resilient communities might look 
like. The background and analysis that follows is based upon a unique participatory action research (PAR) project that partnered with a challenged community in upstate New York. This impoverished community reflects national trends in the disproportionate health disparities suffered by African Americans, including according to a recent report in terms of the distribution of Covid-19 cases (Rome Sentinel, July 2020). The results of this study offer both context and insight about how policies addressing poverty reduction may offer pathways for reducing the risk to global pandemics among minority communities.

\section{Historical and Contemporary National Setting}

In the following, I review work that has identified compounding disparities across multiple intersecting dimensions to offer context for why African Americans are more likely to develop co-morbidities like asthma, cancer, heart disease, diabetes, and obesity, which are associated with Covid-19 infection and death (CDC, 2020). These include (1) housing discrimination which concentrated many African Americans in dense inner cities, often located in environmental toxic regions. These areas transformed over time into (2) unsafe neighborhoods, where domestic violence and street crime were normalized, and (3) food deserts that denied African Americans healthy dietary options. And then when impoverished African Americans developed physical and mental illness related to environmental carcinogens, unhealthy diets, and daily exposure to violence, they were often excluded from (4) quality health services available to the affluent.

\section{Housing Discrimination and Segregated Communities}

Residential segregation patterns based upon race across many US cities date back to the early 1900s, when communities of color were often legally forced to live in overcrowded, poorly maintained housing, isolated from White populations, especially in the Jim Crow south. Meanwhile, government and private sector housing development and real estate programs since the New Deal of the 1930s racialized the availability of home ownership across the nation through redlining in some cases, and others like Levitt home neighborhoods, overtly disallowing Black ownership $[11,13]$. Despite 60 years of dismantling these racist social policies, recent segregation patterns seem unaffected by the rising socioeconomic status of racial minorities since the success of the Civil Rights legislation criminalized forced segregation [19, 22].

One mechanism for this inertia is revealed in Department of Housing and Urban Development (HUD) paired audits, where prospective renters and buyers of different races approach the same landlord or home seller. A series of these HUD studies over the past four decades have concluded that
African Americans and Hispanics or Latinos have experienced consistent adverse treatment during their rental searches, for example, not receiving follow-up calls or experiencing higher rates of rudeness from prospective landlords [12].

Discrimination in these cases also involved being offered less information about rental units and fewer opportunities to view the actual apartment $[9,34]$. Though more recent research has identified some improvement in residential equity over the years [38], residential discrimination continues in perhaps more subtle ways. There is a suggestion that HUD's recent sampling bias may have resulted in an underestimation of the true and current extent of residential discrimination. It failed to calibrate enough for housing that is not listed through popular sources $[10,29]$. Calculating this factor into the formula produced results that suggest the problem of residential discrimination persists. In combination, these facts may explain why mid-1970s Section 8 housing subsidies have not succeeded in breaking residential segregation patterns. Poor minorities may enjoy lower rent; however, they are often herded into more densely packed, less safe housing and neighborhoods.

Moreover, US Whites enjoy 13 times the wealth of African Americans [16]. One key explanation for this is disparities in home ownership, perhaps the most significant means for accumulating wealth for ordinary US citizens. The HUD audit mentioned earlier also revealed that for those minorities posing as potential homebuyers, they were more likely to be guided into less wealthy neighborhoods with a higher proportion of minority residents. Moreover, they were less likely to receive assistance with financing [39]. In addition, for those that were offered home financing, there have often been glaring inequities there too.

Before the mortgage crisis of the 2000s, cross-racial studies that evaluated how minorities secured home loans concluded that African American and Latinos or Hispanics faced higher rejection rates and less favorable terms in securing mortgages than did Whites with similar credit scores [33]. Oliver and Shapiro [28], meanwhile, reported that African Americans were paying more than $5 \%$ higher interest rates on home mortgages than Whites, when controlling for key factors. The irony is that a decade later, after President Clinton deregulating the financial sector and later President W. Bush made it easier for low-income citizens to purchase a home, these same underprivileged minority populations were targeted for predatory subprime loan offers that many could not possibly repay in the run-up to the mortgage crisis of the late 2000s [7, 8]. Not surprisingly, since the mortgage crisis, homeownership rates for minorities have fallen three times the rate of Whites [16]. Predatory practices like these spill over to the day-to-day consumer experiences of racial minorities as well. And this is no better illustrated than in the concept of food deserts, or the empirical fact that poor, minority 
communities are less likely to have proximate access to affordable, quality food in their neighborhoods. Thus, they are more at risk for co-morbidities like heart disease, diabetes, and obesity, which have been associated with Covid-19 infection and death.

\section{Food Deserts}

Chung and Myers [5] found that residents of poor neighborhoods pay more for groceries at their local stores. Moreover, Lewis et al. [18] found that poorer neighborhoods have fewer healthy food options compared with non-poor neighborhoods. Meanwhile, Powell et al. [30] found that poor neighborhoods have $25 \%$ less available supermarkets compared with middleincome neighborhoods.

Not surprisingly, the food desert figures based on poverty levels reflect similar findings by race and ethnicity. Block and Kouba [2] found that predominantly African American neighborhoods had fewer supermarkets. Concurrently, Lewis et al. [18] concluded that African American neighborhoods have fewer healthy food options, often forced to pay more for unhealthy processed fast food, which has been associated with higher rates of heart disease, diabetes, and obesity, preexisting conditions that are all strongly associated with Covid-19 infection and death [4]. Block et al. [3] also found that majority of African American neighborhoods have six times more fast-food restaurants than White neighborhoods. Finally, a Mari Gallagher Research and Consulting Group [21] study uncovered that African Americans travel the farthest to reach a grocery store. Like Section 8 subsidies allow poor minorities to afford low-quality, often overcrowded housing, Johnson-era food stamp subsidies seem to allow them access to low-quality food that compromises their long-term health.

The previous review of studies on housing disparities and food deserts mirrors research on the geographical isolation of poor minority communities. This isolation is often related to the issue of higher levels of violent crime, unsafe domiciles, environmentally toxic neighborhoods, and mental illness related to concentrated poverty, conditions that many minority poor are economically compelled to live in.

\section{Safe Neighborhoods}

One way impoverished neighborhoods pose risks to residents is through the very housing structures and natural environments within which the minority poor have historically been forced to live [24]. Poor minorities are disproportionately exposed to lead and other toxins in their homes due in part to their tight budgets. Their lack of resources, combined with housing discrimination mentioned earlier, narrows the choice of disorganized neighborhood and older buildings they can afford to live in. The dense neighborhoods and overcrowded buildings they often live in, unfortunately, are the least maintained and most likely not up to safety code. This infrastructure disorder has been associated with social disorder, which then often creates the ideal setting for violent crime [15]. The concentrated nature of many poor, minority neighborhoods also means that during a pandemic, the rate of infection is likely to be higher compared with less dense affluent neighborhoods.

Meanwhile, four decades of research on environmental racism have clearly identified the association between poverty, racial minority status, and exposure to toxic pollution either from neighboring industry or land dumps $[17,23,31,37]$. The result is higher rates of cancer and respiratory problems among those communities that neighbor industrial corridors. It should be noted that both pre-existing respiratory problems and cancer are pre-existing conditions that are both strongly associated with Covid-19 infection and death [4]. This heightened risk to environmental harm is due to the historical, racial discrimination in housing markets and the lack of resources needed to move out of toxic structures and regions, which many impoverished African American communities have been economically compelled to live in. But it is also due to a unique proclivity of the economic development community in some US regions to promote the citing of more industry near impoverished neighborhoods. Land prices and leases for industrial use around these impoverished regions are usually a bargain. Moreover, neighboring poor, minority communities have the least access to the knowledge, social contacts, and economic and political resources needed to effectively protest and evict polluting industry.

However, geographical health disparities by race involve more than just a disproportionate exposure to toxic environments. Concentrated poverty is also associated with other negative physical and mental health outcomes. For example, a longitudinal clinical trial study randomly selected an experimental group of low-income, public-housing residents to receive HUD vouchers. This allowed some residents to relocate to higher-income neighborhoods, while others continued living in public housing. A decade later, "voucher" recipients demonstrated lower rates of heart disease, obesity, and diabetes compared with a control group, who stayed behind [20]. In a more recent ecological study, Stevens et al. [36] found a significant association between neighborhood poverty and diabetes-related, lower-extremity amputations. More poverty translated into more amputations. Studies like these add to the growing evidence that the geographical location one grows up in and/or moves to directly impacts their health [25]. Compounding the heightened overall health risk to living in poor communities, minorities in poverty are less likely to have health coverage or access to preventative healthcare. 


\section{Disparities in Health Services}

Though Obamacare stabilized healthcare coverage for many living near or at poverty levels, disparities persist. For example, minorities, especially Latinos or Hispanics, made up over half of those uninsured even during the Obamacare era [1]. The issue of health equity is clouded though by how US states inconsistently accepted Johnson-era Medicaid expansion during the Obama administration, as well as the ongoing debate about whether "coverage" translated into actual "meaningful access" to healthcare. Given the dramatic rise in the cost of insurance deductibles $(67 \%$ increase for some plans from 2010 to 2015), paying for healthcare, even when covered, has at times become prohibitive [14].

Moreover, according to survey data from the National Center for Health Statistics (NCHS), in 2014 6\% of children below the poverty level were uninsured compared with $4 \%$ of children above $200 \%$ of the poverty level [26]. For adults ages 18 to 64 , in 2012 the NCHS data indicate that $32 \%$ of those below the poverty level were uninsured compared with only $9 \%$ of those above $200 \%$ of the poverty level $[6,35]$.

Preventative care is another important dimension identified by NCHS across which disparities exist. For example, the rates for mammograms vary by income level. Only $50 \%$ of women at or below the poverty level received yearly exams compared with $77 \%$ of women at $400 \%$ or more of the poverty level. Meanwhile for colorectal tests, $1 \%$ of adults at or below the poverty level were examined compared with $63 \%$ of those at $400 \%$ or more of the poverty level. This tragic brew of intersecting and compounding factors experienced in isolated, overcrowded, low-income, minority communities reinforces the cycle of health risks to underlying conditions like asthma, cancer, diabetes, heart disease, and obesity, all of which are considered by the CDC [4] as strongly associated with Covid-19 infection and death.

In the following, I explain a unique Participatory Action Research (PAR) project in Upstate New York that addressed the intersectionality of poverty, especially that experienced by minority populations. According to recent reports from Oneida county, where Utica is located, African Americans are approximately 1.5 times more likely as a proportion of their population to succumb to Covid-19 infection [32]. This figure reflects national trends, where African Americans nationwide are 1.5 times more likely to die from Covid-19 compared with whites. The research process and findings of this grassroots study offers policymakers a model for a bottom-up approach for better understanding, and by extension perhaps better mitigating, the health risks experienced in minority, poor communities. This may help safeguard African Americans from future global pandemics.

\section{Research Setting and Methods}

Since 2000, the poverty rate in greater Oneida County in central, upstate New York, where Utica is located, has increased approximately 3 percentage points, rising to $15 \%$. This figure is higher than that of the state (12\%), but on par with that of the nation $(14.7 \%)$. While this county-level increase seems relatively modest, given the steep economic downturn and sluggish recovery over the past decade, it hides a more tragic reality. When the focus is on Oneida County's largest city, Utica, its poverty rate of $32.2 \%$ is alarmingly over twice the national average.

Reflecting national figures, poverty in Utica is not equally distributed. As depicted in Chart 1, the city's 25- to 34-yearold females have the highest poverty rate among all age/ gender groups, with 18- to 24-year-old females not far behind. These are working-aged women in their prime mothering years.

More concerning is that according to a recent local report, Utica has the state's highest youth poverty rate at $43.8 \%$ compared with $25 \%$ in Oneida County, $16 \%$ in the state, and $22 \%$ in the nation. It is important to note that adolescent children 6 to 11 years old, and then toddlers under 5 years old, were identified as the next groups most in poverty. It is very likely these are the children of the mother-aged, young, minority women in poverty mentioned previously, reflecting clearly the social mechanism for intergenerational poverty.

Along with rising poverty rates, Utica has experienced a demographic shift since 2000, owing much to the influx of international refugees. For example, the population of Asians increased 206\% (due to the recent influx of Nepalese and Bhutanese refugees), Hispanics or Latinos by $64 \%$, and African Americans by $12 \%$. The greater Utica region's White population, meanwhile, is still approximately $87 \%$ of the total, a decrease of $6 \%$ since 2000 . Not surprisingly, among racial and ethnic groups, there are disparities among poverty levels. According to the 2015 census, while Whites comprise the majority of those in poverty in Utica (43\% of the total), African Americans and Hispanics or Latinos have the

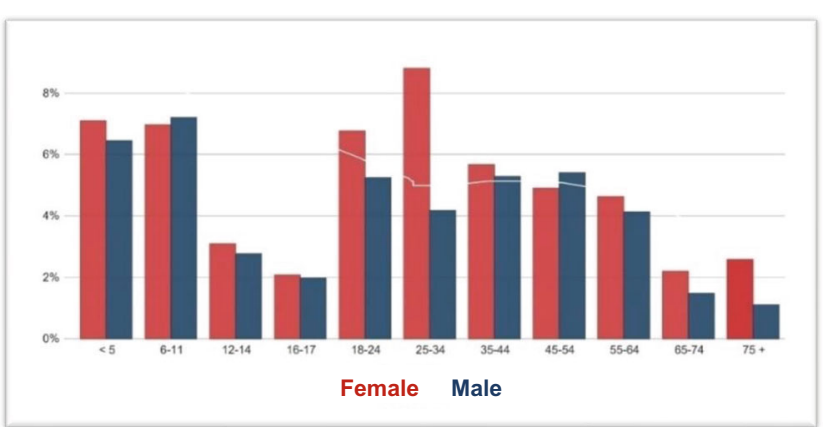

Chart 1 Poverty by age and gender group in Utica. Source: Census Bureau, 2017 
highest per capita poverty rate, 42 and $44 \%$, respectively, compared with only $13 \%$ of White residents.

Youth poverty has already been identified as an extreme cause for concern in the Utica region. But here too, race and ethnicity matter. Poverty is highest among African American children (61\%), with Hispanic or Latino children (49\%) close behind, compared with only $18 \%$ of White children. These are much greater child poverty rates (almost twice as much) compared with state levels, where approximately $34 \%$ of African American children, $25 \%$ of Hispanic or Latino children, and $12 \%$ of White children in New York State are identified as being in poverty. It is important to note that disparity figures along race, gender, and age reflect similar patterns at the national level. Young minority women and their children are the most at risk for poverty in Utica as well as the nation.

Due to the higher poverty rates experienced by most racial groups in the greater Utica region, dependency on state programs has magnified. Applications for New York State assistance have risen over 2 percentage points in Utica since 2000. To put this in perspective, the present Utica-wide rate of assistance applications, which is close to $5 \%$, is 2.5 times greater than that of the New York State average.

Moreover, like national trends, poverty in Utica is geographically distributed unequally too as depicted on Map 1. Poorer communities depicted by the lighter blue to gray are often segregated in the central part of the city, where access to important public resources like markets, healthcare, and education is not readily available.

Compounding this is the lack of access to many betterpaying jobs that are often located outside the city center. The concentration of jobs is to the south and west in the wealthier and Whiter neighborhoods of New Hartford and New York Mills. To access better-paying jobs, the poor must often travel outside their home area, incurring travel costs and delays, while also being separated from their neighborhoods and families for most of the day.

In addition, geo-social and environmental health risks in Utica also reflect historical national figures. As indicated on

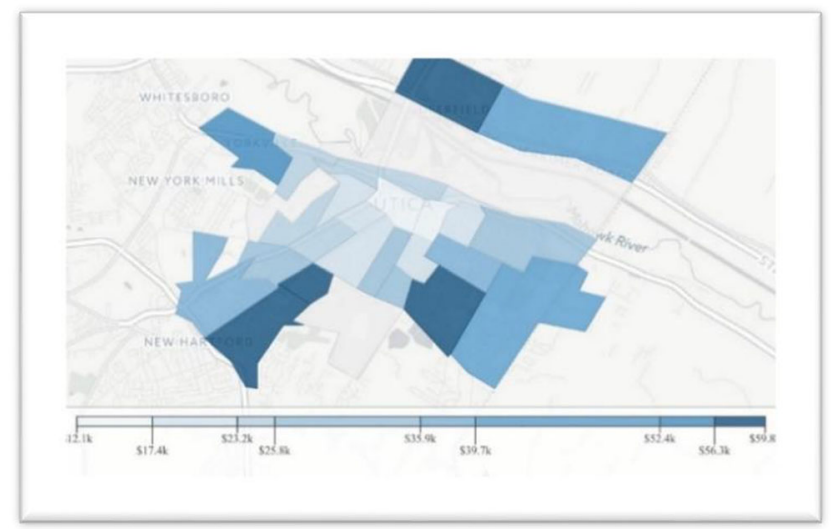

Map 1 Map of poverty in Utica. Source: U.S. Census Bureau, 2017

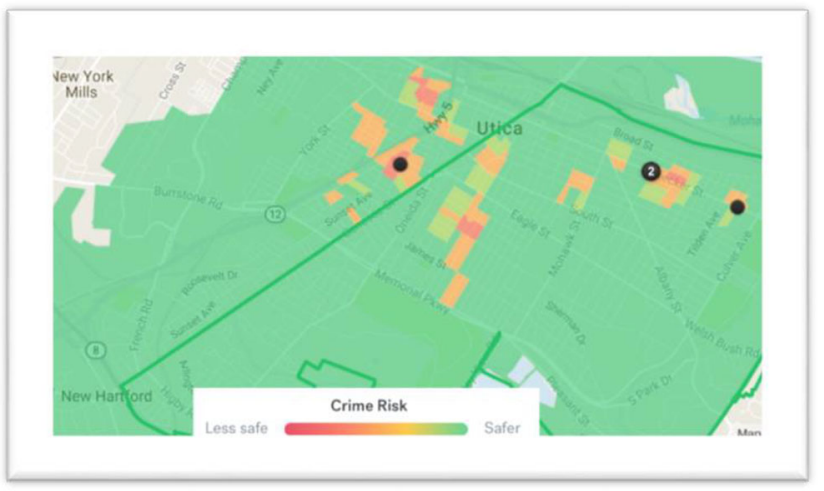

Map 2 Crime by neighborhood in Utica. Source: Tulia.com, 2017

Map 2 in red and orange, higher crime risk is concentrated in many of the centralized areas depicted in lighter blue and gray in the income disparity Map 2, where the majority, who are in poverty, are more likely to live.

Finally, historically, Utica's childhood lead poisoning rate was 2nd highest per capita in New York State. As indicated in Map 3, exposure to carcinogens is more pronounced where poor minority residents live (West Utica and Corn Hill). Over the past three decades, poor minority children in Utica were more than 3 times as likely to have elevated blood lead levels compared with their poor White counterparts [27].

\section{The Empire State Poverty Reduction Initiative-a Participatory Research Project}

To address enduring poverty rates in the state of New York, Governor Cuomo's office identified sixteen cities around the state in need of innovative assistance. With a poverty rate twice the national average, Utica was chosen as one of those cities. Situated in Oneida County, Utica is a medium-sized, upstate New York city with a population of 62,000 . It is geographically located within the Mohawk Valley at the southern

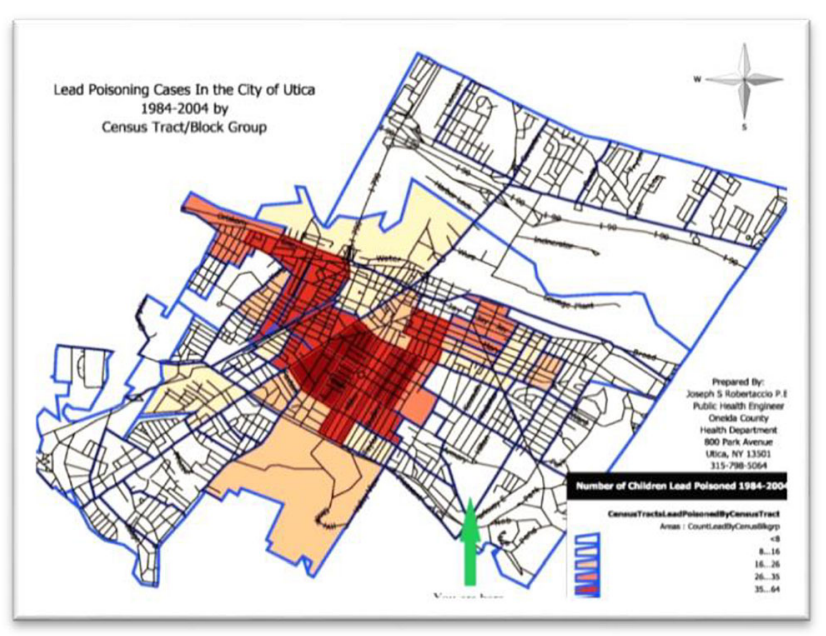

Map 3 Lead poisoning by neighborhood in Utica. Source: Oneida County Health Department [27] 
foot of the Adirondacks, about halfway between the state's capital, Albany to the west, and regional metropole Syracuse to the east. A city where working-aged women and minorities are disproportionately impoverished, and with the state's highest child poverty rate, Utica reflects many of the compounding, interinstitutional causes and cumulative, intergenerational consequences experienced in other impoverished regions of the country.

To develop and oversee the governor's hoped-for innovative project, the state contracted with Utica's United Way office to develop and shepherd the Empire State Poverty Reduction Initiative (ESPRI). Engaging a variety of community, public, and non-profit agencies, ESPRI's mission was to produce grassroots knowledge about poverty in Utica in order to base a bottom-up, poverty reduction recommendation for the governor's office to consider funding for up to $\$ 1.5$ million.

ESPRI represents the culmination of a 5-year effort by federal, state, local agencies to better understand the obstacles to achieving self-sufficiency among Utica's working poor. Building upon a 2015 U.S. Department of Housing and Urban Development (HUD) Community Needs Assessment (CNA), during the first half of 2017 the United Way Utica office conducted focus groups, one-on-one survey, and working-group meetings with over 600 Utica residents, a large majority of them impoverished. The Community Needs Assessment (CNA) study was coordinated by HUD in collaboration with New York State's Housing and Community Renewal (HCR) office, City of Utica Mayor's Office, the Department of Urban and Economic Development (UED), Cornell Cooperative Extension Rust to Green (R2G) office, the Utica Urban Studio, Central New York Veterans Outreach Center, and The Genesis Group. The findings from this research represent the "voices of the community" across a variety of institutional dimensions related to their day-to-day struggles.

The following outlines the various qualitative and quantitative methodologies and sampling strategies ESPRI employed during its community research phases, including key findings. This report then overviews the racial and geographical disparities associated with poverty in Utica, many of which mirror national trends presented previously. This is followed by a summary of the two of the working-group meetings with community stakeholders that produced recommendations on how to resolve the intersecting, institutional barriers constraining Utica's poor from self-sufficiency related to lack of access to quality housing and health services.

\section{The ESPRI Community Research Phases}

From 2017 through 2018, ESPRI organized three research phases:
(1) Focus groups

(2) One-on-one interviews

(3) Working-group meetings

These three phases were arranged in an open and inclusive manner in order to elicit the "voice of the community" along with benefiting from the expertise of key community partners. The following reviews these three phases that produced important community knowledge about poverty in Utica.

During the early part of 2017, ESPRI held twelve focus groups around Utica that included 280 poor residents (approximately 23 participants per focus group). Four of these focus groups took place in community centers located north, south, east, and west Utica neighborhoods and one at the Refugee Center. And additional seven focus groups took place in municipal housing buildings. Through their community contacts, ESPRI organizers encouraged low-income residents to attend and share their experiences about:

(1) The various barriers that poverty creates for them as well as

(2) Their knowledge about community resources to alleviate poverty that are available.

Because of the growing ethnic diversity of the city, interpreters were present during the focus group phase to assist the ESPRI facilitators clarify their prompt questions and translate participant responses to the whole group. To translate for Somali-Bantu-, Spanish-, Arabic-, Bosnian-, and Russianspeaking participants, multiple interpreters were requested.

Each of the twelve focus groups was set up with various round tables, around which subgroups of 4 to 6 poor residents converged. Participants in each subgroup had a sticky notepad to write on each sticky a "one sentence barrier" they experienced. The sentences were then discussed by the subgroup at each table and placed together into categories (similar or overlapping topics) onto a flip chart located at each table. Then, the subgroups discussed what resources or agencies, organizations, churches, and government programs were available in the community to address the barriers they had listed. Each table also had a facilitator, who assisted in systematically listing on that table's flip chart the various resources the subgroup identified. After this phase, many residents reported learning about resources that they were not previously aware of. A reporter for each table then shared with the whole focus group the barriers and relevant resources their subgroup had identified. After the reporting stage, each focus group participant received six colored sticky dots. They were asked to consider the information about various barriers across all the flip charts and then place their six colored dots on what they considered to be the top barriers identified across the subgroup tables. Then, facilitators calculated the dots to determine which barriers were the most relevant or important to the whole focus 
group. After the flip charts were collected, each barrier sentence recorded, and dot information aggregated from all the twelve focus groups, nine major institutional themes emerged that were associated with poverty in Utica, including housing (i.e., expensive, absentee slumlords, unhealthy and isolated from public services) and health and wellness (i.e., expensive, uncoordinated, and often located beyond walking or short bus distance).

Chart 2 indicates that with 625 total sticky-dot votes (30\% of the total votes cast), focus group participants considered justice system issues by far the most important obstacles to alleviating poverty. Education barriers were a distant second, garnering 311 votes $(15 \%)$, while workforce development earned $254(12.3 \%)$ and health and wellness $250(12 \%)$ votes.

ESPRI also conducted one-on-one survey interviews with 195 impoverished citizens living in Utica. ESPRI staff, interns, and volunteers visited soup kitchens, churches, and other agencies that are known to serve clients that are impoverished: 91 surveys were completed with respondents at the Municipal Housing Authority; 78 with respondents at the Johnson Park Center; 18 with respondents at the Hope House; 6 with respondents at the Grace Church; and 2 with respondents at the Veteran's Outreach Center.

In order to be as inclusive as possible, ESPRI created and administered a visual "icon survey" (Fig. 1) that allowed participants to indicate their response without requiring them to be able to read or write. Icons represented the eight institutional dimensions that were identified in the focus group phase. Respondents were asked to circle the icons that they felt would improve their life and then put an X over the icon that would "MOST" improve their life.

\section{Instrument}

After tallying the survey results out of 1044 circles and 248 $\mathrm{Xs}$, health and wellness was calculated to be the number one dimension (349 circles and $81 \mathrm{Xs}$ ) to improving this sample respondents' lives (Tables 1 and 2). Education was a distant second with 108 circles, and funding and money priorities was a distant second for highest priority with $38 \mathrm{Xs}$.

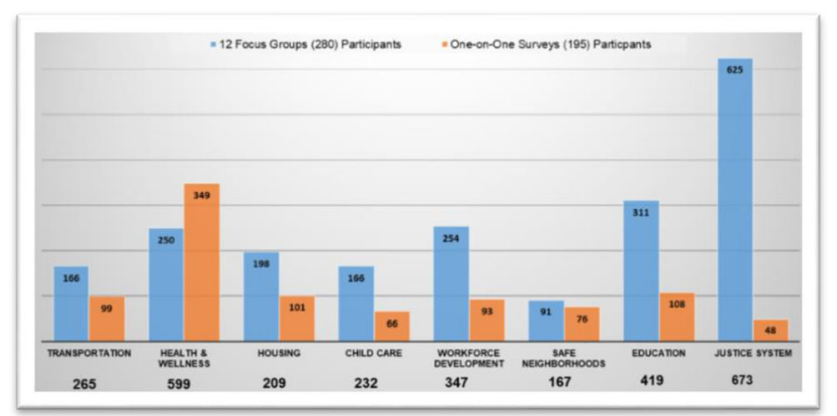

Chart 2 Comparing focus group and survey results. Source: ESPRI 2017

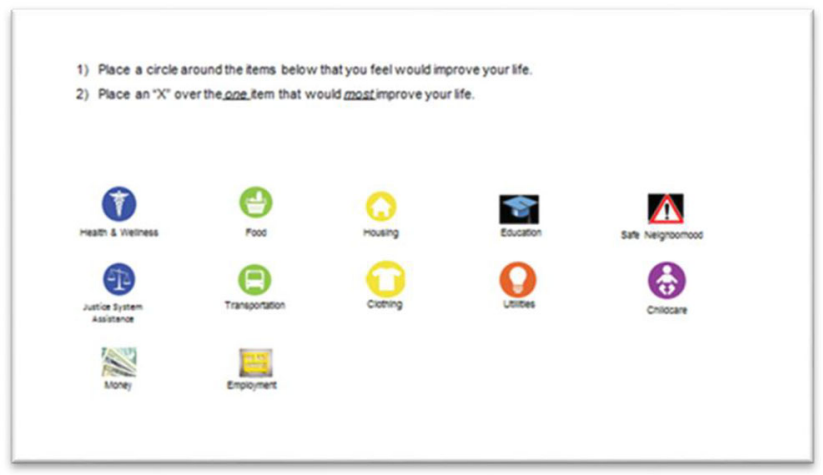

Fig. 1 One-on-one survey interview instrument

Funding and money priorities (104) and housing and resources (101) were the second and third most circled. Meanwhile, education and employment priorities were tied for third most important with $30 \mathrm{Xs}$ each.

Comparing focus group and survey results, Chart 2 indicates that the survey participants reported health and wellness with more frequency compared with focus group participants, who reported criminal justice issues with more frequency. One explanation for this disparity is that focus group participants were drawn from mainly impoverished communities that deal with justice system issues on a daily basis. Meanwhile, interview respondents were drawn from perhaps the most-at-risk segment of the impoverished community, for example, the elderly and the homeless. These two at-risk populations are more likely to find healthcare, food, and clothing as more pressing concerns than perhaps issues with the justice system.

The nine interconnected institutional "obstacles" identified in the focus group phases, and supported by the survey phase, then formed the basis for eight, separate working-group meetings held around the Utica area during June 2017. The ninth obstacle, institutional racism, was embedded in discussions of each of the eight dimensions. Working-group meetings were attended by relevant stakeholders, representing impoverished community members, service providers, the city government, and area academics - about 20 per working group for an approximate total of 160 participants over all eight meetings.

Each working group also had two session chairs in attendance, totaling sixteen. These individuals, which were drawn mainly from the non-profit world relevant to that particular institutional obstacle, would champion the "voice of the community" from their working group during successive phases of the project.

Meanwhile, in assembling the participants for these eight working groups, ESPRI employed a quota sample to ensure that at least $50 \%$ of the participants would be below the federal poverty line and 50\% above that line. Participants for the working-group phase were recruited from the original 12 focus groups. There were also several self-identified 
Table 1 Utica Empire State Poverty Reduction Initiative survey results

\begin{tabular}{|c|c|c|c|c|c|c|c|c|c|c|}
\hline $\begin{array}{l}\text { Survey } \\
\text { location }\end{array}$ & $\begin{array}{l}\text { No. of } \\
\text { surveys } \\
\text { collected }\end{array}$ & $\begin{array}{l}\text { Health } \\
\text { and } \\
\text { wellness }\end{array}$ & $\begin{array}{l}\text { Health and } \\
\text { wellness } \\
\text { priority }\end{array}$ & $\begin{array}{l}\text { Housing } \\
\text { and } \\
\text { resources }\end{array}$ & $\begin{array}{l}\text { Housing and } \\
\text { resources } \\
\text { priority }\end{array}$ & Education & $\begin{array}{l}\text { Education } \\
\text { priority }\end{array}$ & $\begin{array}{l}\text { Safe } \\
\text { neighborhoods }\end{array}$ & $\begin{array}{l}\text { Safe } \\
\text { neighborhoods } \\
\text { priority }\end{array}$ & Justice \\
\hline $\begin{array}{l}\text { Municipal } \\
\text { housing } \\
\text { Authority }\end{array}$ & 91 & 91 & 18 & 40 & 5 & 47 & 10 & 24 & 5 & 11 \\
\hline $\begin{array}{c}\text { Johnson Park } \\
\text { Center }\end{array}$ & 78 & 185 & 45 & 43 & 9 & 46 & 16 & 33 & 4 & 25 \\
\hline $\begin{array}{l}\text { Veteran's } \\
\text { Outreach } \\
\text { Center }\end{array}$ & 2 & 4 & 0 & 1 & 0 & 1 & 0 & 2 & 0 & 1 \\
\hline Grace Church & 6 & 14 & 4 & 3 & 1 & 4 & 0 & 4 & 0 & 2 \\
\hline Hope House & 18 & 55 & 14 & 14 & 5 & 10 & 4 & 13 & 3 & 9 \\
\hline Priority totals & & & 81 & & 20 & & 30 & & 12 & \\
\hline Totals & 195 & 349 & & 101 & & 108 & & 76 & & 48 \\
\hline
\end{tabular}

Source: ESPRI 2018

participants. Additional participants were identified by ESPRI's core team, steering committee, and work-group chairs, who were asked to recruit co-workers, employees, and clients. Each person that inevitably participated in a working group was pre-screened to determine their eligibility for a "below-poverty" stipend in order to offset their lost wages or cost of childcare in order to participate.

Chart 3 indicates that $61 \%$ of working group participants were in poverty, $72 \%$ were female, $52 \%$ were from multi-ethnic backgrounds, 29\% were White, and 9\% were African American, while Asian/Pacific Islanders and Hispanic/Latino made up 5\% each. Meanwhile, the most represented age group was " 50 to 64 " years old (33\%), followed by "35 to 49" years old (30\%).

Each working-group meeting included an orientation to the ESPRI project-to-date, its unique community-up and integrated process, and recent census and community research findings relevant to the particular institutional "obstacle" discussed. Attendees were then assembled into four heterogenous subgroups of from 4 to 6 members. It was important that each group included at least two working-poor and/or impoverished members in order to ensure the "voice of the community" was represented in each subgroup.

ESPRI organizers then guided these four subgroups through discussion and debate about the most important four barriers and available and potential community resources associated with each of the eight institutional obstacles identified in the research phases. Using flip charts and guided by a facilitator, each heterogenous subgroup then identified additional barriers to the ones that were found in the focus group stage. The subgroups then evaluated the known community resources and potential ones to resolving the various specific barriers associated with their institutional obstacle.

Table 2 Utica Empire State Poverty Reduction Initiative survey results

\begin{tabular}{|c|c|c|c|c|c|c|c|c|c|c|}
\hline $\begin{array}{l}\text { Survey } \\
\text { location }\end{array}$ & $\begin{array}{l}\text { No. of } \\
\text { surveys } \\
\text { collected }\end{array}$ & $\begin{array}{l}\text { Justice } \\
\text { priority }\end{array}$ & Transportation & $\begin{array}{l}\text { Transportation } \\
\text { priority }\end{array}$ & Childcare & $\begin{array}{l}\text { Childcare } \\
\text { priority }\end{array}$ & $\begin{array}{l}\text { Funding } \\
\text { and } \\
\text { money }\end{array}$ & $\begin{array}{l}\text { Funding and } \\
\text { money } \\
\text { priority }\end{array}$ & Employment & $\begin{array}{l}\text { Employment } \\
\text { priority }\end{array}$ \\
\hline $\begin{array}{l}\text { Municipal } \\
\text { Housing } \\
\text { Authority }\end{array}$ & 91 & 1 & 44 & 10 & 28 & 6 & 46 & 18 & 48 & 15 \\
\hline $\begin{array}{l}\text { Johnson Park } \\
\text { Center }\end{array}$ & 78 & 3 & 40 & 1 & 29 & 5 & 39 & 11 & 30 & 8 \\
\hline $\begin{array}{l}\text { Veteran's } \\
\text { Outreach } \\
\text { Center }\end{array}$ & 2 & 0 & 1 & 1 & 2 & 1 & 1 & 0 & 1 & 0 \\
\hline Grace Church & 6 & 0 & 1 & 0 & 2 & 0 & 5 & 4 & 2 & 0 \\
\hline Hope House & 18 & 3 & 13 & 4 & 5 & 2 & 13 & 5 & 12 & 7 \\
\hline Priority totals & & 7 & & 16 & & 14 & & 38 & & 30 \\
\hline Totals & 195 & & 99 & & 66 & & 104 & & 93 & \\
\hline
\end{tabular}

Source: ESPRI 2018 


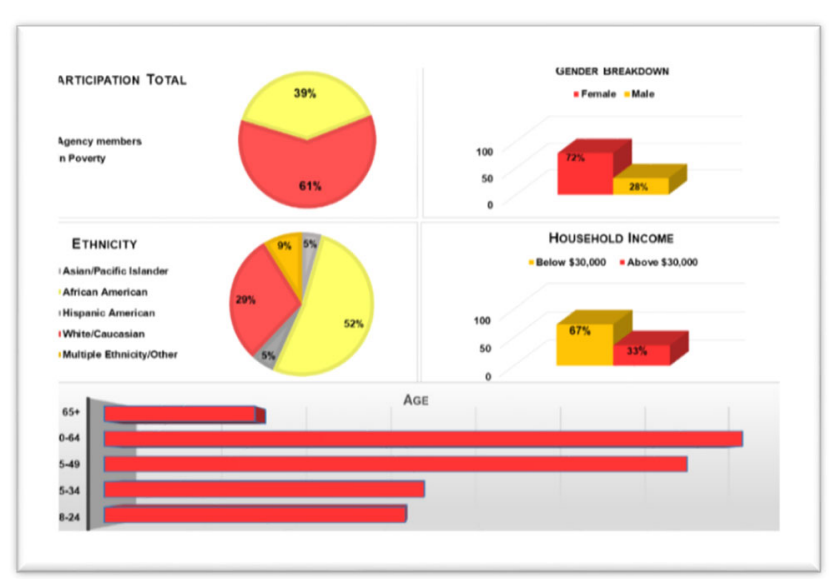

Chart 3 Working group demographic breakdown. Source: ESPRI 20117

A subgroup member then reported out to the whole working-group meeting about their table's workable solutions for their particular barrier. Using colored sticky dots like during the focus group stage, the entire working group then publicly voted for their favorite solution developed from within each subgroup table. ESPRI organizers then added up all the dots to determine the most popular solution for each group.

Based upon approximately five hours of guided learning, discussions, debates, brainstorming, and public voting, each of the eight working-group sessions generated four recommendations that addressed key dimensions of that institutional obstacle. These recommendations were then critically evaluated and compared over the next several months to determine the most important recommendation the community would eventually vote upon. The following findings section focusses on the recommendations that emerged from the workinggroup session on health obstacles.

\section{Identifying and Addressing Health Challenges in Utica}

Access to healthcare has been a historical priority of the U.S. Welfare System since the 1930s post-Great Depression era. It was made even more central in the 1960s Johnson-era welfare innovation of Medicare and Medicaid. These programs have been expanded ever since, including forming a crucial component of Clinton's 1990s Welfare Reform policies. Without access to affordable Healthcare, TANF was not predicted to be successful. Obama's Patient Protection and Affordable Care Act or commonly referred to as Obamacare hoped to expand coverage to even more US citizens during his two terms. However, debates continue about whether extending coverage actually translated into access to affordable care.

The importance of healthcare cannot be underestimated. Even when employment and educational opportunities are available, missed work and classes due to illness or the illness of close family members neutralize the potential benefits and may lead to layoffs and low grades or even expulsion from school. Moreover, undiagnosed or untreated mental illness and drug addiction can have reverberating impacts within families and communities. The working poor and minorities are most likely to suffer from this unfortunate dynamic, further under-privileging them, while magnifying the stigmas they already experience. Health figures from Utica along with the community knowledge gathered during the ESPRI process reflect similar patterns of under-privilege by class and race.

That data available on health disparities in the greater Utica area are comprehensively compiled at the country level. First, the proportion of mothers receiving early prenatal care (beginning in the first trimester of pregnancy) declined by 5 percentage points in Oneida County since 2000. This decline is especially marked for minority mothers. In 2014 , only $58 \%$ of African American and 61\% of Latino mothers in Oneida County experienced early prenatal care, compared with $64 \%$ of African American and 69\% of Latino mothers statewide. Meanwhile, the proportion of babies born with low birth weight was $8 \%$ in Oneida County from 2012 to 2014, higher compared with the state rate of $7.5 \%$.

In 2014, 2.4\% of births in Oneida County were premature, a sharp increase over the previous year and higher than the state rate at $1.7 \%$. Teen pregnancy, meanwhile, declined from 2000 to 2014 in Oneida counties as well as the state. From 2012 to 2014, about 4\% of teens in Oneida County became pregnant, compared with about $3 \%$ for the state. The percentage of out-of-wedlock births though was much higher for Oneida County $(51 \%)$ compared with those of the state $(40 \%)$ and nation $(40 \%)$. This reflects a quarter-century national uptrend that is highly associated with rising poverty rates among single women with dependent children.

When looking closer at many of the dimensions already considered, the most recent data available indicates that race is a major mediating factor in Utica. Table 3 shows additional disparities among different races. African Americans are more likely to suffer high per-capita mortality rates and premature deaths in Oneida County (lines 1 and 2). Line 4 indicates that African American have less access to adequate prenatal care (51.7\%) compared with Whites (76.1\%). Also, they are more likely to suffer premature births $(21.9 \%)$ compared with Whites $(10.8 \%)$, low birthweight births $(15.5 \%)$ compared with Whites $(7.0 \%)$, and infant mortality per rates $(21.6 \%)$ compared with Whites (5.5\%)-lines 5, 6, and 8. Though down, African American teen pregnancies are substantially higher (51\%) compared with those of Whites $(9.7 \%)$-line 7.

African Americans are also more likely to suffer more than twice the asthma rates and be hospitalized for respiratory disease substantially more than Whites-lines 9 and 10 . Moreover, African Americans in Utica have higher mortality rates associated with heart attacks, strokes, diabetes, and cancer compared with Whites (lines 11-16). African Americans are also more likely to suffer colorectal and breast cancer compared with whites (lines 17-19). Finally, African 
Table 3 Oneida County Health Indicators by Race/Ethnicity, 2012-2014

\begin{tabular}{|c|c|c|c|c|c|}
\hline \multirow[t]{2}{*}{ Health indicator } & \multicolumn{3}{|c|}{ Non-Hispanic } & \multirow[t]{2}{*}{ Hispanic } & \multirow[t]{2}{*}{ Total } \\
\hline & White & Black & Asian/Pacific Islander & & \\
\hline \multicolumn{6}{|l|}{ General health indicators } \\
\hline 1. Total mortality per 100,000 population & 738.5 & 953.8 & 448.6 & 521.9 & 743.4 \\
\hline 2. Percentage of premature deaths $(<75$ years $)$ & $34.6 \%$ & $72.0 \%$ & $53.8 \%$ & $75.3 \%$ & $36.8 \%$ \\
\hline \multicolumn{6}{|l|}{ Birth-related indicators } \\
\hline 3. Number of births per year (3-year average) & 1929 & 232 & 156 & 188 & 2584 \\
\hline 4. Percentage of births with adequate prenatal care & $76.1 \%$ & $51.7 \%$ & $51.4 \%$ & $62.6 \%$ & $70.9 \%$ \\
\hline 5. Percentage of premature births ( $<37$ weeks gestation) & $10.8 \%$ & $21.9 \%$ & $15.2 \%$ & $17.1 \%$ & $12.6 \%$ \\
\hline 6. Percentage of low birthweight births $(<2.5 \mathrm{~kg})$ & $7.0 \%$ & $15.5 \%$ & $7.1 \%$ & $11.1 \%$ & $8.1 \%$ \\
\hline 7. Teen pregnancies per 1000 females aged $15-17$ years & 9.7 & 51.0 & 12.7 & 36.6 & 23.5 \\
\hline 8. Infant mortality per 1000 live births & 5.5 & 21.6 & 4.3 & 7.1 & 7.5 \\
\hline \multicolumn{6}{|l|}{ Respiratory disease indicators } \\
\hline 9. Asthma hospitalizations per 10,000 population & 9.6 & 19.7 & 13.3 & 7.2 & 11.4 \\
\hline 10. Chronic lower respiratory disease hospitalizations per 10,000 population & 33.2 & 52.2 & 22.1 & 13.3 & 353 \\
\hline \multicolumn{6}{|l|}{ Heart disease and stroke indicators } \\
\hline 11. Diseases of the heart mortality per 100,000 population & 193.9 & 286.9 & 114.5 & 109.9 & 195.4 \\
\hline 12. Diseases of the heart hospitalizations per 10,000 population & 88.0 & 114.2 & 28.3 & 29.6 & 91.5 \\
\hline 13. Cerebrovascular disease (stroke) mortality per 100,000 population & 32.0 & 54.9 & 32.6 & 20.4 & 33.0 \\
\hline 14. Coronary heart disease mortality per 100,000 population & 134.5 & 193.8 & 68.0 & 49.5 & 134.7 \\
\hline 15. Congestive heart failure mortality per 100,000 population & 10.6 & 13.6 & 24.1 & 0.0 & 10.6 \\
\hline \multicolumn{6}{|l|}{ Diabetes indicators } \\
\hline 16. Diabetes mortality per 100,000 population & 21.9 & 28.7 & 0.0 & 13.5 & 21.5 \\
\hline \multicolumn{6}{|l|}{ Cancer indicators } \\
\hline 17. Colorectal cancer mortality per 100,000 population & 13.7 & 31.8 & $\mathrm{n} / \mathrm{a}$ & $\mathrm{n} / \mathrm{a}$ & 14.0 \\
\hline 18. Colorectal cancer incidence per 100,000 population & 35.1 & 45.3 & $\mathrm{n} / \mathrm{a}$ & $\mathrm{n} / \mathrm{a}$ & 35.0 \\
\hline 19. Female late-stage breast cancer incidence per 100,000 female population & 37.5 & 47.4 & $\mathrm{n} / \mathrm{a}$ & $\mathrm{n} / \mathrm{a}$ & 37.3 \\
\hline \multicolumn{6}{|l|}{ Substance abuse and mental health-related indicators } \\
\hline 20. Drug-related hospitalizations per 10,000 population & 15.0 & 17.7 & $\mathrm{n} / \mathrm{a}$ & 6.6 & 15.3 \\
\hline
\end{tabular}

Source: Department of Health, New York State (revised August 2016)

Americans are more likely to be hospitalized for drug-related reasons (line 20). Asthma, cancer, heart disease, and diabetes are all considered pre-existing conditions strongly associated with Covid-19 infection and death [4].

Cumulatively, these figures underscore the historical racial disparities by health, while also offering explanation for why a recent report indicated that African Americans in Oneida County are overrepresented among Covid-19 cases [32]. African Americans make up about $11 \%$ of confirmed Covid19 cases in the county, yet only make up 7\% of the county's residents.

As important as healthcare is, it is not surprising to learn that Utica residents were on par with statewide residents in requesting information on healthcare-approximately $7 \%$ (Chart 4). Utica residents did request more information about food (approximately $12 \%$ compared with approximately $8 \%$ ), but less about mental health and addictions (7.5\% compared with $4 \%$ ).

From June 2015 to April 2017, Utica residents requested 2-1-1 information a cumulative $21 \%$ across healthcare, mental care and addiction, and food (Chart 5). Only the combination of housing, utilities, and household needs (30\%) was requested at a higher frequency. However, the lack of these important resources and services is interrelated with higher health risks as well.

As indicated in Table 4, ESPRI survey respondents from Utica's impoverished community across four locations were asked to circle if health, food, clothing, utilities, and money were a barrier to self-sufficiency. They were also asked to cross with an $\mathrm{X}$ if these were major priorities. Ninety-one Municipal Housing Authority respondents (100\%) circled this combination of options, while only $19.8 \%$ (18 out of 91 ) 
selected these as priorities. Two-thirds of Hope House's 18 respondents circled this combination of options, while over one-third selected them as priorities. Finally, thirty of the 78 Johnson Park Center respondents (38\%) circled this combination, while only $10 \%$ ( 8 out of 78 ) identified this combination of health-related issues as priorities.

Many of the concerns over health disparities were reflected in both the HUD Community Needs Assessment CNA and latter ESPRI study (identified in the parentheses).

1 Lack of programs (ESPRI)

2 Limited healthy food choices (ESPRI and CNA)

3 Limited behavioral health (CNA)/mental illness assistance (ESPRI)

4 Lack of wraparound services (CNA)/support services (ESPRI)

5 Substance abuse (CNA)/addiction (ESPRI)

6 Limited healthcare coverage (ESPRI)

7 Lack of affordable healthcare (ESPRI and CNA)/high deductibles-co-pays (ESRI)

8 Lack of healthcare providers-specialty physicians (ESPRi and CNA)

Other institutional obstacles that overlapped with health issues were also identified. These included:

\section{Transportation (ESPRI and CNA) — health facilities are} far

2 Justice system (ESPRI) — criminalization of mental health and drug addiction

These combined studies helped form the basis for a dedicated working-group meeting during June 2017, focused exclusively on health. The findings from this collaborative session are reviewed next.

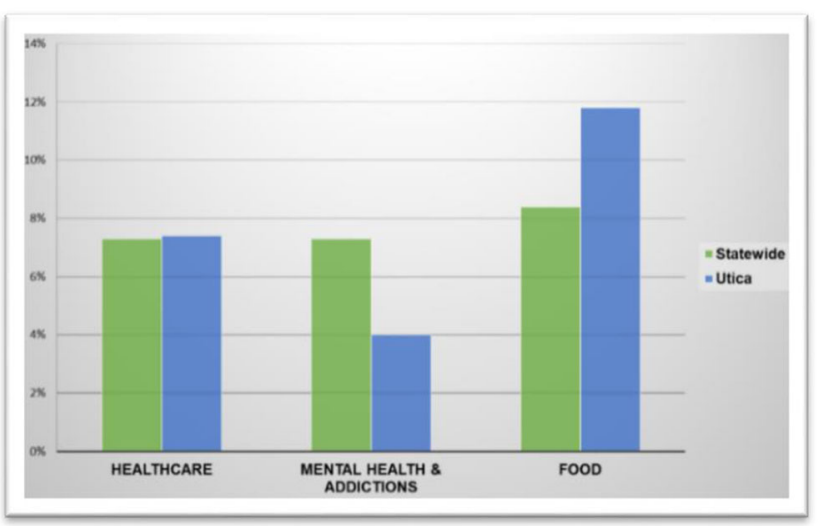

Chart 4 State and Utica comparison on health referrals. Source: ESPRI 2017

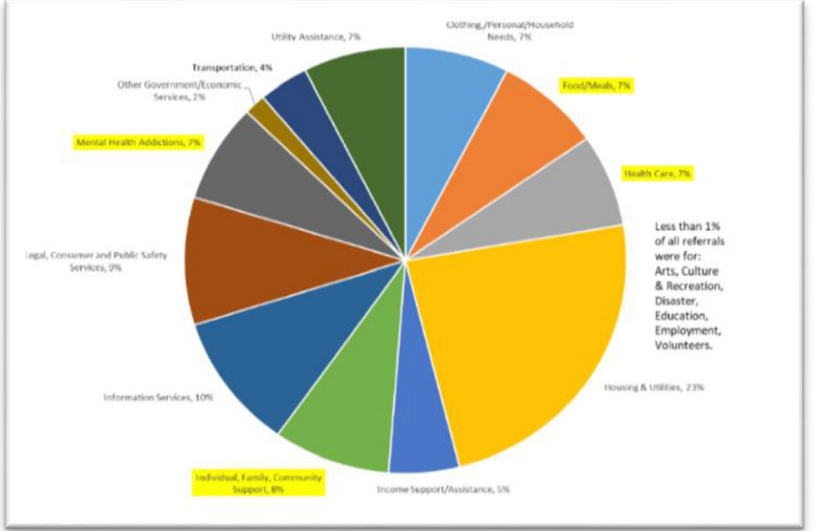

Chart 5 2-1-1 content center Utica health referrals. Source: ESPRI 2017

\section{ESPRI Obstacles and Solutions to Health Disparity}

The overlap in community concerns about health issues that were voiced in both the ESPRI and CNA research stages formed the basis for a June 2017 ESPRI working-group meeting focused on the health dimension. A group of approximately 20 impoverished community members, non-profit representatives, city officials, and academics were assembled into four groups. Each group addressed one barrier and the available community resources associated with it. The groups then discussed and debated health solutions. The following includes the top recommendation from each of four subgroups, after the entire working group voted using colored sticky dots.

One subgroup addressed the general barriers to affordable comprehensive healthcare, an issue that the workplace development working group also considered. Though expanding Medicaid has helped many, for the working poor just outside the Medicaid requirements, Obamacare-era coverage has increased co-pays and deductible, making access too expensive.

To address the disparity in access to health, this group proposed comprehensive universal healthcare, which included mental, dental, vision, and also drug addiction care.

Another subgroup addressed the lack of healthy affordable housing and support services. They proposed increasing affordable single-residency occupancy for the working poor to become independent from social services. Limited to working adults, the studio apartment housing complex this subgroup proposed would include onsite life coaching to help the homeless transition to self-sufficiency. The group acknowledged that HUD has a model for transitional housing up to 24 months, which their idea could build upon.

Reflecting national patterns, the barrier of limited and affordable healthy food options was another one a subgroup addressed. Poor and minority communities are often geographically isolated from access to health food options. This subgroup recommended subsidizing local farmers and fresh produce trucks to increase supply, while doubling snap benefits for fresh produce at farmers' markets to increase demand. 
Table 4 ESPRI health and wellness survey results

\begin{tabular}{llll}
\hline Survey site & No. of surveys collected & $\begin{array}{l}\text { Health and } \\
\text { wellness }\end{array}$ & $\begin{array}{l}\text { Health and wellness } \\
\text { priority }\end{array}$ \\
\hline $\begin{array}{l}\text { Municipal Housing } \\
\quad \text { Authority }\end{array}$ & 91 & 91 & 18 \\
Johnson Park Center & 78 & 185 & 45 \\
Veteran's Outreach Center & 2 & 4 & 0 \\
Grace Church & 6 & 14 & 4 \\
Hope House & 18 & 55 & 14 \\
\hline
\end{tabular}

Source: ESPRI 2017
The combination could make organic local farming and distribution competitive and sustainable, while providing more healthy and affordable food to those who most need it.

Another national pattern reflected in Utica was the lack of healthcare education, awareness, and communication. The subgroup discussing this dimension recommended Marketing Utica Community Health Programs through a 211-like health information hotline. The one proposed though would be more effectively marketed within at-risk communities.

Also discussed in the general group was how health knowledge needs to be disseminated across local sources other than commercial ones. There were questions about how trustworthy health reports were on popular news shows, since so many of them rely on pharmaceutical industry advertising dollars. Moreover, some additional funds should be made available to impoverished communities for transportation to local farmers' markets since fresh produce trucks do not always visit certain neighborhoods. Meanwhile, to address the winter storage issue, some suggested training citizens on food-preserving techniques as well as the creation of a co-op storage center. Also, perhaps offering an indoor farmer's market or support hydroponic farming for winter production might offer additional year-round access to healthy options.

The recommendations offered in this working group represent feasible pathways to addressing the health gaps Utica's minority poor suffer from. Offering them quality (1) comprehensive health services through an expanded Medicaid or even a single-payer system, (2) safe housing in organized neighborhoods, (3) healthy food options, and (4) education on healthy living choices could help reduce the underlying conditions (e.g., respiratory issues, cancer, heart disease, diabetes, and obesity), which make this population more susceptible to infection and death to global pandemics like Covid-19.

\section{Conclusion}

Racial disparities in deaths from health issues are due to a variety of intersectional factors. Minorities tend to be poorer and are less likely to afford effective medical care. For example, the Centers for Disease Control (CDC) indicates that during the 2012-2013 US flu season, White people received the most flu shots (44.6\%) while African Americans received the least $(35.6 \%)$. Though the figures are not completely available for Oneida County, the racial disparities in deaths from flu-related causes have been reflected in New York as well. African Americans are the New York racial group that is most at risk from this type of death (Chart 6).

It is not surprising then that as of June 2020, African Americans account for $25 \%$ of the New York deaths due to Covid-19, yet they make up only $14 \%$ of the state's population (Covidtracking.com). And one of the compounding issues that may be the key to this disparity is related to the underlying health conditions or co-morbidities exhibited by those who suffer Covid-19 infections and, tragically, deaths.

In Utica, African Americans are more likely to suffer from underlying health conditions like respiratory conditions, cancer, heart disease, obesity, and diabetes. Respiratory issues

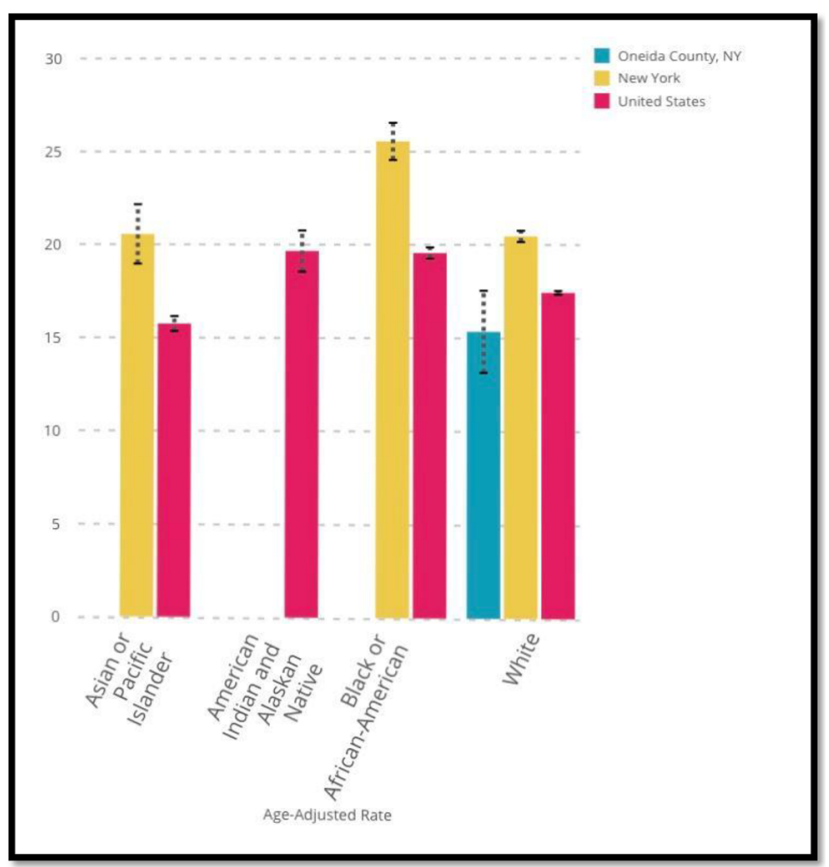

Chart 6 Influenza and pneumonia deaths per 100,000: by race (2008). Source: Centers for Disease Control 
and cancer can often be a result of toxic domiciles and neighborhood environments, in which many poor minorities are compelled to live for historical racial and contemporary economic reasons. Heart conditions, meanwhile, can be related to stress (unemployment, violent homes and neighborhoods) and the lack of healthy food options (food deserts). Meanwhile, obesity and diabetes are related to the lack of healthy food options as well. Each of these medical challenges is exasperated by the lack of health information and access to periodic quality healthcare, which impoverished minority Uticans report, which may explain why African Americans in this upstate New York region are 1.5 times more likely as proportion of their local population to succumb to Covid-19 infection [32].

Finally, while a comprehensive single-payer healthcare system might be a necessary factor to reduce racial disparities in health information and service, it is argued here that reducing racial disparities in housing, safe neighborhoods, goodpaying jobs, and the proximate access to quality food could be the sufficient factors to help increase African Americans' resilience to health-related causes of death including future global pandemics like Covid-19. Policymakers across nations should take note of how the ESPRI project results presented in this paper mirror, while adding grassroots authenticity, to this argument.

\section{Compliance with Ethical Standards}

Conflict of Interest The author declares that he has no conflict of interest.

\section{References}

1. Artiga S, Ubri P, Foutz J, Damico A. Health coverage by race and ethnicity: examining changes under the ACA and the remaining uninsured. Issue Brief. Kaiser Family Foundation. 2016. https:// www.kff.org/disparities-policy/issue-brief/health-coverage-byrace-and-ethnicity-examining-changes-under-the-aca-and-theremaining-uninsured/. Accessed 11/25/2019

2. Block D, Kouba J. A comparison of the availability and affordability of a market basket in two communities in the Chicago area. Public Health Nutr. 2006;9(7):837-45.

3. Block JP, Scribner RA, DeSalvo KB. Fast food, race/ethnicity, and income. Am J Prev Med. 2004;27(3):211-7.

4. CDC - Centers for Disease Control and Prevention. Evidence used to update the list of underlying medical conditions that increase a person's risk of severe illness from COVID-19. 2020. URL: https:// www.cdc.gov/coronavirus/2019-ncov/need-extra-precautions/ evidence-table.html. Accessed 08/20/2020.

5. Chung C, Myers SL. Do the poor pay more for food? An analysis of grocery store availability and food price disparities. J Consum Aff. 1999;33(2):276-96.

6. Cohen RA, Martinez ME Health insurance coverage: early release of estimates from the National Health Interview Survey, 2014. National Center for Health Statistics. 2013. https://www.cdc.gov/ nchs/data/nhis/earlyrelease/Insur201303.pdf. Accessed 11/25/2017
7. Dymski G, Hernandez J, Mohanty L. Race, gender, power, and the US subprime mortgage and foreclosure crisis: a meso analysis. Fem Econ. 2013;19(3):124-151. https://doi.org/10.1080/13545701. 2013.791401.

8. Faber JW. Racial dynamics of subprime mortgage lending at the peak. Hous Policy Debate. 2013;23(2):328-49.

9. Feins JD, Bratt RG. Barred in Boston: racial discrimination in housing. J Am Plan Assoc. 1983;49:347-57.

10. Freiberg F, Squires GD. Changing contexts and new directions for the use of testing. Cityscape. 2015;17(3):87-101.

11. Gotham K. Racialization and the state: the Housing Act of 1934 and the creation of the Federal Housing Administration. Sociol Perspect. 2000;43(2):291-317.

12. Hakken J. Discrimination against Chicanos in the Dallas rental housing market: An experimental extension of the housing market practices survey. Washington, D.C.: U.S. Department of Housing and Urban Development; 1979.

13. Hillier AE. Redlining and the home owners' loan corporation. J Urban Hist. 2003;29(4):394-420.

14. Kaiser Family Institute. Employee health benefits 2015 annual survey: employee cost sharing. Kaiser Family Foundation and the Health Research \& Educational Trust. 2015. http://files.kff.org/ attachment/report-2015-employer-health-benefits-survey. Accessed 1/05/2020

15. Kelling G, Coles C. Fixing broken windows: restoring order and reducing crime in our communities. New York: Free Press; 1998.

16. Kochhar R, Fry R. Wealth inequality has widened along racial, ethnic lines since end of Great Recession. PEW Research Center; 2014. http://www.pewresearch.org/fact-tank/2014/12/12/racialwealth-gaps-great-recession/. Accessed 11/24/2017.

17. Lee C. Beyond toxic wastes and race. In: Bullard RD, editor. Confronting environmental racism: voices from the grassroots. Boston: South End Press; 1993. p. 41-52.

18. Lewis LB, Sloane DC, Nascimento LM, Diamant AL, Guinyard JJ, Yancey AK. African Americans' access to healthy food options in South Los Angeles restaurants. Res Pract. 2005;95(4):668-73.

19. Logan JR Separate and unequal in suburbia. Census Brief prepared for Project US2010. 2014. http://www.s4.brown.edu/us2010. Accessed 11/24/2017

20. Ludwig J, Sanbonmatsu L, Gennetian L, Adam E, Duncan GJ, Katz LF, et al. Neighborhood, obesity, and diabetes — a randomized social experiment. N Engl J Med. 2011;365:1509-19.

21. Mari Gallagher Research \& Consulting Group. Examining the Impact of Food Deserts on public Health in Chicago; 2006. http://www.marigallagher.com/projects/4/. Accessed 1/4/2018.

22. Massey DS, Denton NA. American apartheid: segregation and the making of the underclass. Cambridge: Harvard University Press; 1998.

23. Mohai P, Bryant B. Race, poverty, and the environment. EPA J. 1992;18(1):6-8.

24. Moody H, Darden JT, Pigozzi BW. The racial gap in childhood blood lead levels related the racial gap in childhood blood lead levels related to socioeconomic position of residence in metropolitan Detroit. Sociol Race Ethn. 2016;2(2):200-18.

25. Najman JM, Bor W, Ahmadabadi Z, Williams GM, Alati R, Mamun AA, et al. The inter- and intra- generational transmission of family poverty and hardship (adversity): a prospective 30 year study. PLoS One. 2018;13(1):e0190504. https://doi.org/10.1371/ journal.pone.0190504.

26. National Center for Health Statistics - NCHS. Health, United States, 2016: with chartbook on long-term trends in health. Hyattsville: U.S. Department of Health and Human Services; 2017. URL Accessed 11/12/2017: https://www.cdc.gov/nchs/data/ hus/hus16.pdf 
27. Nitti L. The lead catastrophe in Utica. Love and rage. 2015. https:// loveandragemedia.org/2015/11/14/the-lead-catastrophe-in-utica/. Accessed 11/18/2017.

28. Oliver M, Shapiro T. Black wealth, white wealth: a new perspective on racial inequality. New York: Routledge; 1997.

29. Pitingolo R, Ross SL. Housing discrimination among available housing units in 2012: do paired-testing studies understate housing discrimination? Cityscape. 2015;17(3):61-85.

30. Powell L, Auld C, Chaloupka F, O'Malley PM, Johnston LD. Associations between access to food stores and adolescent body mass index. Am J Prev Med 2007;33(4).

31. Roberts JT. Chronicles from the environmental justice frontline: Cambridge University Press; 2001.

32. Rome Sentinel. 32 new COVID cases in Oneida County. 2020. https://romesentinel.com/stories/32-new-covid-cases-in-oneidacounty,100283. Accessed 08/15/2020.

33. Ross S, Yinger J . Does discrimination in mortgage lending exist? The Boston Fed study and its critics. The Urban Institute. 1999.

34. Roychoudhury C, Goodman AC. An ordered probit model for estimating racial discrimination through fair housing audits. J Hous Econ. 1992;2:358-73.

35. Smith JC, Medalia C. Health insurance coverage in the United States: 2014, U.S. Census Bureau, Current Population Reports. In: Health insurance coverage in the United States. Washington,
DC: U.S. Government Printing Office; 2014. p. 60-253. URL Accessed 11/25/2010: https:/www.census.gov/content/dam/ Census/library/publications/2015/demo/p60-253.pdf.

36. Stevens C, Schriger D, Raffetto B, Davis A Zingmond D, Roby DH. Geographic clustering of diabetic lower-extremity amputations in low-income regions of California health affairs, 33 (8). 2015. https://www.healthaffairs.org/doi/full/10.1377/hlthaff.2014.0148. Accessed 01/12/2020

37. Taylor DE. Toxic communities: environmental racism, industrial pollution, and residential mobility: NYU Press; 2014.

38. Turner MA, Santos R, Levy DL, Wissoker D, Aranda C, Pitingolo R. Housing discrimination against racial and ethnic minorities 2012. Washington, DC: U.S. Department of Housing and Urban Development; 2013.

39. Turner MA, Ross SL, Gaister GC, Yinger J. Discrimination in metropolitan housing markets: national results from phase 1 HDS 2000. Washington, DC: Urban Institute, HUD; 2002. http://www. huduser.org/intercept.asp?loc=/Publications/pdf/Phase1_Report. pdf. Accessed 04/15/2020.

Publisher's Note Springer Nature remains neutral with regard to jurisdictional claims in published maps and institutional affiliations. 